\title{
Surveillance of nasal and bladder cancer to locate sources of exposure to occupational carcinogens
}

\author{
Kay Teschke, Michael S Morgan, Harvey Checkoway, Gary Franklin, John J Spinelli, \\ Gerald van Belle, Noel S Weiss
}

\begin{abstract}
Objective-To locate sources of occupational exposure to nasal and bladder carcinogens for surveillance follow up in British Columbia, Canada.

Methods-Incident cases of nasal cancer $(n=48)$, bladder cancer $(n=105)$, and population based controls $(n=159)$ matched for sex and age, were interviewed about their jobs, exposures, and smoking histories. Odds ratios (ORs) were calculated for 57 occupational groups with stratified exact methods to control for age, sex, and smoking.
\end{abstract}

Results-Occupational groups at increased risk of nasal cancer included: textile workers ( $\mathrm{six}$ cases, OR 7.6); miners, drillers, and blasters (six cases, OR 3.5); welders (two cases, OR 3.5); pulp and paper workers (three cases, OR 3.1); and plumbers and pipefitters (two cases, $O R$ 3.0). Nasal cancer ORs were not increased in occupations exposed to wood dust, possibly due to low exposures in local wood industries. Strongly increased risks of bladder cancer were found for sheet metal workers (four cases, OR 5.3), miners (19 cases, $O R$ 4.5), gardeners (six cases, $O R$ 3.7), and hairdressers (three cases, $O R$ 3.2). Among occupations originally considered at risk, the following had increased risks of bladder cancer: painters (four cases, OR 2.8); laundry workers (five cases, OR 2.3); chemical and petroleum workers (15 cases, OR 1.8); machinists (eight cases, OR 1.6); and textile workers (three cases, OR 1.5).

Conclusions-Occupational groups with increased risks and three or more cases with similar duties were selected for surveillance follow up. For nasal cancer, these included textile workers (five were garment makers) and pulp and paper workers (three performed maintenance tasks likely to entail stainless steel welding). For bladder cancer, these included miners (12 worked underground), machinists (five worked in traditional machining), hairdressers (three had applied hair dyes), and laundry workers (three were drycleaners).

(Occup Environ Med 1997;54:443-451)

Keywords: textile industry; paper; wood; mining; occupational exposure
Traditional disease surveillance has used vital statistics data bases to examine patterns of mortality in occupations and industries and generate hypotheses for further epidemiological study. ${ }^{1}$ After the definition by Rutstein $e t a l^{2}$ of occupational sentinel health events, many recent surveillance efforts have aimed to provide a more direct impetus to action, including treatment of patients, screening for disease in coworkers, and investigations into industrial hygiene at associated work sites. ${ }^{3}$ Few such studies have investigated cancer outcomes, ${ }^{4-6}$ although 13 cancers are listed as occupational sentinel health events. ${ }^{2}$ There may be several reasons.

Cancers have long induction and latent periods, so sources of exposure may no longer exist by the time the case is identified. Although this will often be true, recent studies of mesothelioma led to the discovery of previously unrecognised current sources of exposure to asbestos. ${ }^{5}$ This is especially important evidence of the potential value of cancer surveillance, as asbestos is one of the best known industrial hazards of this century. Sources of other carcinogens are likely to be less well recognised.

Studies that followed the sentinel event approach of Rutsein et al have identified case series, then used case by case evaluations to assess the relation of a disease event to work. ${ }^{346}$ The ability to assess aetiology on an individual basis was a criterion for selecting diseases for the United States sentinel event notification system for occupational risks (SENSOR). ${ }^{3}$ For cancer, and most other diseases on the sentinel events list, it would be difficult to attribute cause on an individual basis, as most cancers with occupational aetiologies also occur in the absence of such exposures. Surveillance would require analytical methods which compare groups.

We conducted a surveillance study of three cancer types, mesothelioma, nasal cancer, and bladder cancer, with case-control methodology. It was designed to locate sources of occupational exposure to known or probable carcinogens in the province of British Columbia, Canada, with the aim of alerting regulatory agencies and industrial health professionals about occupations that warranted occupational hygiene exposure measurement, and control. This paper reports the results for nasal and bladder cancer, both of which have several known occupational aetiologies, as well as non-industrial aetiologies, in particular, smoking. The results for mesothelioma are reported elsewhere. $^{7}$ 
Materials and methods

IDENTIFICATION OF CASES

All incident cases with histologically confirmed primary malignant tumours of the nasal cavity or sinuses (ICD-O topography codes 160.0 and 160.2 to 160.9 ), and urinary bladder (ICD-O 188) age $\geqslant 19$ and registered by the British Columbia Cancer Agency (BCCA) were considered eligible for the study. The registry of the BCCA is population based and for case ascertainment uses reports from all provincial pathology and haematology laboratories, death notices from the British Columbia Division of Vital Statistics, reports from other Canadian registries about cancers in residents of British Columbia, and admission records from BCCA clinics. A BCCA pathologist, not blinded to the initial diagnosis, reviewed tissue samples for every case initially identified as eligible.

The study period was 1 September 1990 to 31 August 1992 for nasal cancer, to allow accrual of about 50 cases, and 1 September 1990 to 31 May 1991 for bladder cancer, sufficient for accrual of at least 100 cases. As people with an industrial background have often been found to develop bladder cancer at younger ages than those with other backgrounds, ${ }^{8-10}$ cases of bladder cancer were restricted to those born after 31 December 1915.

\section{SELECTION OF CONTROLS}

Controls were randomly selected from fiveyear age and sex strata of the provincial voters list updated to 17 July 1991 . Those eligible included all residents of British Columbia who were Canadian citizens aged $\geqslant 19$ and who were not in prison or confined to a mental health institution by court order. Controls were frequency matched to the age and sex distribution of cases of all three types of cancer included in the study. All study controls within two years of age of the cases were included in the analyses for each cancer site.

\section{INTERVIEWS}

The methods of contacting subjects in this study were reviewed and approved by the University of British Columbia Behavioural Sciences Screening Committee. All subjects living within about six hours surface travel time of Vancouver (one way) were interviewed either in person or by telephone, at their convenience. The remaining interviews were conducted by telephone $(21 \%$ for cases and $23 \%$ for controls).

If a subject did not speak English well or had trouble recalling events in his or her life, a relative chosen by the subject was asked to translate or help with the interview. If the subject was dead, the surviving next of kin who had most recently lived with the subject was contacted for interview. An attempt was made to frequency match next of kin control interviews to the number of next of kin case interviews within age-sex strata. However, when no next of kin was available or the request for a next of kin interview would have resulted in a refusal, the interview was conducted with the control instead.
Interviews were conducted with a standardised questionnaire based on a prototype originally developed by the United States National Cancer Institute to investigate occupational associations with mesothelioma. ${ }^{11}$ It included occupational, residential, smoking, and medical histories, and an exposure history aimed at identifying exposures considered by the International Agency for Research on Cancer (IARC) $)^{12-16}$ to be known or probably carcinogenic. Interviews were conducted with a standardised questionnaire. For this study, questions about specific exposures and work processes relating to nasal and bladder cancer were added. An interview guide was used to aid recall of exposure; it listed types and trade names of products in which carcinogens were used. Data for the interview guide was obtained from the Canadian Centre for Occupational Health and Safety trade names data base, the Canadian Pharmaceutical Society, Health and Welfare Canada, and texts. ${ }^{17} 18$

All interviews were conducted by a registered nurse who was aware of the case-control status of the subjects, but was not aware of aetiologies for the specific cancer sites. All interviews were reviewed for completeness by an industrial hygienist (KT) who was not aware of the case-control status of the subjects. Additional information requested by the hygienist (missing data, or further information to clarify tasks or exposures) was sought by the interviewer.

\section{OCCUPATIONAL GROUPS}

All occupations and industries listed were coded to the fourth digit of the standard occupational and industrial classification. ${ }^{19} 20$ In total, 3951 separate jobs were listed by the interviewees, representing over 300 occupational and 500 industrial codes. For analysis, grouping of jobs was necessary. However, collapsing to the third or second digit of the standard classifications was likely to group people with very different exposures (all construction trades together, production and management employees together within an industry), who might be kept separate in a grouping scheme specific to the study.

Such a scheme was therefore developed without knowledge of the case or control status of the people whose jobs were being grouped. When occupation was considered most likely to determine exposures, it was used as the basis for assignment to a group (managers, teachers, truck drivers), and when the industry was judged more likely to determine exposures, such as production and labouring jobs, it was used to assign groups (sawmill workers, railway transport workers). Where both industry and occupation would be expected to determine potential exposures (industrial mechanics, welders, and other tradespeople), occupation was used as the basis for classification.

After the initial assignment to occupational groups, the descriptions of duties and exposures accompanying each job listing were reviewed to ensure the best possible classification-for example, a retail store "manager" who stocked shelves and acted as a 
Table 1 Response characteristics of eligible cases and controls, and characteristics of interviewees

\begin{tabular}{llllll}
\hline & \multicolumn{2}{l}{ Nasal cancer } & & \multicolumn{2}{l}{ Bladder cancer } \\
\cline { 2 - 3 } \cline { 5 - 6 } \cline { 5 - 6 } & Cases & Controls & & Cases & Controls $^{*}$ \\
\hline Total eligible: & 54 & 195 & & 119 & 173 \\
$\quad$ Physician refusal & 1 & NA & & 2 & NA \\
$\quad$ Unable to contact & 0 & 3 & & 3 & 3 \\
Case or control refusal & 5 & 33 & & 8 & 31 \\
Interview incomplete & 0 & 0 & & 1 & 0 \\
Interview complete (\% of eligible) & $48(88.9)$ & $159(81.5)$ & & $105(88.2)$ & $139(80.3)$ \\
Men (\%) & $33(68.8)$ & $128(80.6)$ & & $88(83.8)$ & $112(80.3)$ \\
Age (y, mean(SEM)) & $66.3(1.9)$ & $65.5(0.8)$ & & $64.8(0.8)$ & $63.4(0.8)$ \\
Next of kin interviewees (\%) & $7(14.6)$ & $22(13.8)$ & & $19(18.1)$ & $19(13.7)$ \\
Never smoked & 11 & 36 & & 14 & 31 \\
Ex-smokers & 31 & 88 & & 56 & 75 \\
Current smokers & 6 & 35 & & 35 & 33 \\
Pack-years (mean(SEM)) & $32.3(5.5)$ & $27.3(2.8)$ & & $38.9(3.4)$ & $26.7(3.0)$ \\
\hline
\end{tabular}

* Controls used in the bladder cancer analysis are a subset of those used in the analysis of nasal cancer; 22 were not included because they were born before 31 December 1915 .

$\mathrm{NA}=$ not applicable.

cashier was grouped with sales clerks instead of managers; a motor body shop worker who painted cars was grouped with painters, rather than service station attendants or vehicle mechanics. Finally, occupational groups with $<20$ listings were reviewed to find whether they could be combined with others. In a few instances, this was not considered possible (hairdressers and barbers, laundry personnel, firefighters). In the final classification, all job listings were assigned to one of 57 occupational groups (table 2).

CASE-CONTROL ANALYSIS

Odds ratios (ORs) and $95 \%$ confidence intervals (95\% CIs) were calculated for "ever" (defined as six months of employment or longer) versus "never" employed in each occupational group. Latency analyses were conducted for all occupational groups, with the most recent 20 years of employment removed. Odds ratios were also calculated for 5,10 , and 15 year latencies for all occupational groups which were originally suspected or which had ORs of $\geqslant 2.0$ in the initial ever or never analyses. Effect estimates were also calculated for two duration of employment categories: 6 months to $<10$ years; and $\geqslant 10$ years. These are reported when they influence the interpretation of the results.

All OR estimates were adjusted for sex, age (in three strata: < 60; 60 to 69; and $\geqslant 70$ ), and cigarette smoking. Strata for smoking were based on associations within this dataset for each cancer site, resulting in two strata for nasal cancer (0-19; and $\geqslant 20$ pack-years), and three strata for bladder cancer $(0-9 ; 10-39$; and $\geqslant 40$ pack-years $)$. Sex-specific analyses (men only) were conducted for ever versus never employed in each occupational group. When these showed notable differences compared with the sex adjusted analyses, further investigations were carried out.

Because of the small size of some occupational groups, exact methods were used to summarise ORs across all strata and calculate 95\% CIs. ${ }^{21}{ }^{22}$ All summary ORs and $95 \%$ CIs were calculated with Egret (Statistics and Epidemiology Research Corporation, Seattle, WA, 1993).
The ORs and $95 \%$ CIs were also calculated for occupational exposures to specific agents and processes, and for other factors-for example, diseases, or drugs - considered to be possibly related to nasal and bladder cancer. When non-occupational factors originally suspected were shown to be positively associated, unconditional logistic regression was used to find whether effect estimates for occupational groups with increased relative risks remained the same after adjustment for these additional potential confounders.

\section{SELECTION OF OCCUPATIONS FOR SURVEILLANCE} FOLLOW UP

A standard framework was used to select which occupations were of interest for surveillance follow up. An occupational group was designated for notification of occupational health personnel if $(a)$ it had an OR of $>3.0$ in the ever employed analysis, or an OR $>1.2$ if it was originally considered to be at risk based on a literature review, and (b) at least three cases in the occupational group had a pattern of similar job duties or exposures. Before notification of local regulatory agencies and hygienists, consideration was given to whether the designated jobs were already recognised as associated with cancer in British Columbia. As this final selection process was mainly of local interest, it is not described in detail here.

\section{Results}

COMPARABILITY OF CASES AND CONTROLS

There were six cases of nasal cancer and 18 cases of bladder cancer initially reported by the BCCA that were found on pathology review not to be eligible for the present analysis. Table 1 indicates the response rates of those considered eligible for the study after pathology review. Information was obtained for $80 \%-90 \%$ of both cases and controls, and in most instances from the subjects themselves.

Table 1 also indicates selected descriptive characteristics of the interviewed subjects. Because the cases of bladder cancer and controls were restricted to those born after 1915,22 of the controls selected for the overall study were not eligible for the bladder cancer analysis. The mean ages among cases were similar to controls. There were differences in sex distribution between the cases of nasal cancer and controls, because the frequency matching of controls to cases was based on the distribution for all three cancer sites combined and nasal cancer had a higher proportion of female cases than did mesothelioma or bladder cancer.

\section{NASAL CANCER}

Table 2 shows the ORs and 95\% CIs of associations between the 57 occupational groups and cancers of the nasal cavity and sinuses. Textile workers had a significantly increased risk in the ever employed analysis. Only one exposed case and two exposed controls were men. Sex specific analyses gave ORs of 3.5 (95\% CI 0.1 to 89.3 ) for men and 12.9 (95\% CI 1.3 to 663 ) for women ever employed. All five female cases and the one 
Table 2 Odds ratios ${ }^{*}$ showing associations between occupational groups and cancer of the nasal cavity or sinuses: all cases ( $\left.n=48\right)$ and controls ( $\left.n=159\right)$ included

\begin{tabular}{|c|c|c|c|c|c|c|}
\hline & \multicolumn{3}{|l|}{ Ever employed } & \multicolumn{3}{|c|}{ Most recent 20 years removed } \\
\hline & Cases/controls $n$ & Ever employed $O R$ & $95 \% C I$ & Cases/controls $n$ & Ever employed $O R$ & $95 \% C I$ \\
\hline \multicolumn{7}{|l|}{ Occupational groups with $\mathrm{OR} \geqslant 3.0$ : } \\
\hline Textile workers & $6 / 3$ & 7.6 & $1.4-56.6$ & $4 / 3$ & 5.0 & $0.8-43.0$ \\
\hline Miners, drillers, and blasters $†$ & $6 / 7$ & 3.5 & $0.9-14.6$ & $6 / 7$ & 3.5 & $0.9-14.6$ \\
\hline Welderst & $2 / 4$ & 3.5 & $0.2-53.7$ & $2 / 3$ & 3.9 & $0.2-63.4$ \\
\hline Pulp and paper mill workerst & $3 / 3$ & 3.1 & $0.4-25.4$ & $3 / 3$ & 3.1 & $0.4-25.4$ \\
\hline Plumbers and pipefitters $\dagger$ & $2 / 2$ & 3.0 & $0.2-49.1$ & $2 / 2$ & 3.0 & $0.2-49.1$ \\
\hline \multicolumn{7}{|l|}{ Occupational groups originally suspect: } \\
\hline Painters & $2 / 4$ & 2.2 & $0.2-17.9$ & $2 / 3$ & 2.6 & $0.2-24.8$ \\
\hline Machinists $\nmid$ & $3 / 8$ & 1.9 & $0.3-10.6$ & $3 / 7$ & 2.1 & $0.3-13.4$ \\
\hline Carpenters and wood workers, nect & $6 / 27$ & 1.0 & $0.3-2.9$ & $4 / 25$ & 0.7 & $0.2-2.3$ \\
\hline Smelter and foundry workerst & $2 / 9$ & 0.9 & $0.1-5.3$ & $2 / 7$ & 1.4 & $0.1-9.8$ \\
\hline Chemical and biological laboratory personnel & $2 / 8$ & 0.7 & $0.1-4.0$ & $2 / 7$ & 0.9 & $0.1-5.3$ \\
\hline Forestry and logging workers $\dagger$ & $2 / 13$ & 0.5 & $0.1-2.4$ & $2 / 12$ & 0.5 & $0.1-2.7$ \\
\hline Sawmill workerst & $3 / 22$ & 0.4 & $0.1-1.6$ & $2 / 21$ & 0.3 & $0-1.4$ \\
\hline Shoe and leather workers & $0 / 6$ & 0 & $0-2.8$ & - & - & - \\
\hline \multicolumn{7}{|l|}{ Other occupational groups: } \\
\hline Administrators, managers & $5 / 22$ & 0.7 & $0.2-2.2$ & $3 / 16$ & 0.66 & $0.1-2.7$ \\
\hline Travelling managers and salesmen & $4 / 33$ & 0.4 & $0.1-1.4$ & $4 / 26$ & 0.57 & $0.1-1.9$ \\
\hline Accountants, book-keepers & $7 / 21$ & 1.4 & $0.5-4.0$ & $6 / 13$ & 1.88 & $0.5-6.1$ \\
\hline Engineers, designerst & $0 / 7$ & 0 & $0-4.0$ & - & 1.00 & - \\
\hline Teachers, librarians & $5 / 15$ & 0.9 & $0.2-3.0$ & $5 / 10$ & 1.49 & $0.4-5.4$ \\
\hline Sales clerks & $12 / 41$ & 0.9 & $0.4-2.1$ & $11 / 34$ & 1.06 & $0.4-2.6$ \\
\hline Office clerks and secretaries & $12 / 27$ & 1.2 & $0.4-3.1$ & $11 / 25$ & 1.24 & $0.5-3.2$ \\
\hline Healthcare workers & $4 / 9$ & 1.3 & $0.3-5.6$ & $4 / 8$ & 1.53 & $0.3-6.6$ \\
\hline Radio operators & $0 / 9$ & 0 & $0-1.3$ & - & - & - \\
\hline Surveyors, prospectors, trappers $†$ & $1 / 8$ & 0.5 & $0-42$ & $1 / 8$ & 0.48 & $0-4.2$ \\
\hline Warehouse clerks and labourers & $9 / 35$ & 0.9 & $0.4-2.3$ & $7 / 28$ & 0.96 & $0.3-2.6$ \\
\hline Delivery personnel, unmotorised & $7 / 37$ & 0.6 & $0.2-1.5$ & $7 / 35$ & 0.63 & $0.2-1.7$ \\
\hline Firefighters $\dagger$ & $2 / 5$ & 1.8 & $0.2-13.4$ & $1 / 5$ & 1.02 & $0-11.1$ \\
\hline Guards, policet & $3 / 8$ & 1.6 & $0.2-8.0$ & $3 / 2$ & 9.19 & $0.9-139$ \\
\hline Armed forces personnel, nect & $10 / 37$ & 1.0 & $0.4-2.4$ & $10 / 37$ & 1.0 & $0.4-2.4$ \\
\hline Janitors & $3 / 11$ & 1.4 & $0.2-6.3$ & $1 / 8$ & 0.5 & $0-4.4$ \\
\hline Housekeepers & $8 / 13$ & 1.6 & $0.4-6.7$ & $7 / 12$ & 1.5 & $0.4-6.1$ \\
\hline Handymen and apartment caretakers & $2 / 16$ & 0.4 & $0.0-2.0$ & $0 / 5$ & 0 & $0-3.1$ \\
\hline Laundry personnel & $0 / 4$ & 0.4 & $0-13.9$ & - & - & - \\
\hline Hairdressers, barbers & $1 / 1$ & 2.5 & $0-225$ & $1 / 1$ & 2.5 & $0-225$ \\
\hline Cooks & $4 / 13$ & 0.9 & $0.2-3.0$ & $2 / 10$ & 0.7 & $0.1-3.5$ \\
\hline Food service personnel & $6 / 24$ & 0.7 & $0.2-2.0$ & $6 / 19$ & 1.1 & $0.3-3.2$ \\
\hline Food processors & $7 / 22$ & 1.2 & $0.4-3.4$ & $6 / 22$ & 1.0 & $0.3-3.0$ \\
\hline Farmers and farm labourers & $10 / 44$ & 0.9 & $0.3-2.2$ & $10 / 43$ & 0.9 & $0.3-2.3$ \\
\hline Gardeners $\dagger$ & $3 / 4$ & 2.9 & $0.4-19.8$ & $2 / 4$ & 2.0 & $0.2-16.1$ \\
\hline Fisherment & $0 / 4$ & 0 & $0-6.6$ & -1 & -2.0 & $-1.2-10.1$ \\
\hline Sheet metal workerst & $1 / 2$ & 2.3 & $0-67.2$ & $1 / 2$ & 2.3 & $0-67.2$ \\
\hline Chemical and petroleum workers & $1 / 10$ & 0.4 & $0-2.8$ & $1 / 7$ & 0.6 & $0-5.1$ \\
\hline Construction forement & $2 / 8$ & 0.9 & $0.1-5.0$ & $2 / 5$ & 1.4 & $0.1-10.1$ \\
\hline Construction labourers† & $5 / 23$ & 0.9 & $0.2-2.8$ & $4 / 19$ & 0.7 & $0.2-2.3$ \\
\hline Bricklayers, plasters, and cement workers $\dagger$ & $1 / 7$ & 0.5 & $0-4.8$ & $1 / 5$ & 0.7 & $0-7.7$ \\
\hline Electricians and electrical equipment installers $†$ & $0 / 9$ & 0 & $0-3.6$ & - & $一$ & - \\
\hline Heavy equipment operatorst & $1 / 7$ & 0.5 & $0-4.8$ & $0 / 7$ & 0 & $0-2.6$ \\
\hline Motor vehicle operators & $10 / 28$ & 1.5 & $0.6-3.7$ & $10 / 24$ & 1.9 & $0.7-4.9$ \\
\hline Pilots, aircraft crew $\dagger$ & $2 / 7$ & 1.1 & $0.1-7.1$ & $2 / 7$ & 1.1 & $0.1-7.1$ \\
\hline Railway transport workers, nect & $3 / 8$ & 1.8 & $0.3-9.1$ & $3 / 7$ & 2.1 & $0.3-11.8$ \\
\hline Ship transport workers, nect & $4 / 12$ & 1.4 & $0.3-5.3$ & $4 / 12$ & 1.4 & $0.3-5.3$ \\
\hline Shipbuilding workers, nect & $0 / 5$ & 0 & $0-6.0$ & $\ldots$ & 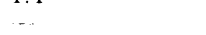 & \\
\hline Transport engineers and firement & $1 / 6$ & 1.0 & $0-13.7$ & $1 / 6$ & 1.0 & $0-13.7$ \\
\hline Stationary engineers, boilermakers $\dagger$ & $2 / 11$ & 0.8 & $0.1-4.4$ & $2 / 11$ & 0.8 & $0.1-4.4$ \\
\hline Service station attendants and managerst & $4 / 19$ & 0.8 & $0.2-2.8$ & $4 / 15$ & 1.0 & $0.2-3.7$ \\
\hline Vehicle mechanicst & $5 / 20$ & 0.9 & $0.2-2.9$ & $5 / 20$ & 0.9 & $0.2-2.9$ \\
\hline Small equipment repairers $\dagger$ & $3 / 10$ & 2.9 & $0.4-18.5$ & $3 / 9$ & 3.8 & $0.5-30.1$ \\
\hline Industrial mechanics $\dagger$ & $2 / 10$ & 1.0 & $0.1-5.5$ & $1 / 9$ & 0.5 & $0-4.3$ \\
\hline
\end{tabular}

* Adjusted for sex, age (in 3 strata: $<60,60-69$, and $\geqslant 70$ years), and cigarette smoking (in two strata: $0-19$ and $\geqslant 20$ pack-years).

+ All exposed cases and controls were men.

No cases, no further analyses done. nec $=$ Not elsewhere classified

female control were employed in garment making. Men in this group had varying jobs, none in garment making. Most of the cases mentioned exposure to fabric dust, and some remarked on the fabric finish, cleaning solvents, and sewing machine oil. None of the textile worker cases had been employed in other occupations found to be at risk in this study or considered beforehand to be at risk. Four of the cases and none of the controls were non-smokers.

Risk estimates $\geqslant 3.0$ were measured in four other occupational groups in the ever employed analysis: pulp and paper mill workers; miners, drillers, and blasters; welders; and plumbers and pipefitters. All exposed cases and controls in these occupations were men. For all except the pulp and paper mill group, risks increased with $\geqslant 10$ years of employment.

An examination of job duties among these occupational groups showed an interesting pattern related to pulp mill employment. Among the welders, one case had worked in pulp and paper mill construction. Many pulp mill piping systems are stainless steel, and welding this metal produces fumes containing nickel and hexavalent chromium. ${ }^{19}$ Two other cases may have had similar exposures: a pulp mill pipefitter (included in both the plumberpipefitter and pulp-paper mill worker occupational groups), and a pulp mill instrument fitter (in the pulp and paper mill group). The 
remaining case who had worked at a pulp mill had no specific job details given, because the interviewee was a next of kin. All of the pulp and paper mill worker controls were involved in production rather than maintenance jobs, and none of the welder or plumber-pipefitter controls reported working in pulp and paper mills or other industries likely to involve stainless steel welding.

The cases in the miners, drillers, and blasters group had widely varying work descriptions, which did not suggest exposures in common. Two worked underground and four above ground.

Among occupational categories originally considered suspect, those involving work with wood or leather had ORs consistently <1.0: sawmill workers; forestry and logging workers; carpenters and woodworkers; and shoe and leather workers. Consistent with the results obtained in the analysis of these occupational groups, ORs were $<1.0$ for occupational exposures to the following agents and processes which have been strongly associated with nasal cancer in other studies: hardwood dust (OR $0.6,95 \%$ CI 0.1 to 3.0 ); softwood dust (OR $0.7,95 \%$ CI 0.3 to 1.6 ); furniture or cabinet making (OR $0.7,95 \%$ CI 0.1 to 3.8 ); boot or shoe manufacture or repair (no cases); and leather tanning or processing (no cases). Chemical and biological laboratory personnel were also not at increased risk of nasal cancer.

Smelter and foundry workers, who might have been exposed to nickel or chromium, showed slightly increased risks only with a 20 year latency period taken into account. Painters had increased risks that increased with latency. Machinists also had raised risks that increased with both duration of exposure and latency. No pattern of duties or exposures was found within any of the occupational groups originally suspected of being at high risk.

The histologies of the nasal cancers in this study included 23 squamous cell carcinomas, seven melanomas, seven lymphomas, two adenocarcinomas, two adenoid cystic carcinomas, and seven other histologies with one case each. A histology specific analysis was judged possible only for squamous cell carcinoma $(n=23)$. One control who was more than two years older than the remaining cases was excluded from the reanalysis $(n=158)$. The following occupational groups had ORs $\geqslant 3.0$ in the ever employed analysis: textile workers (OR $5.3,95 \%$ CI 0.2 to 107 ); sheet metal workers (OR 5.3, 95\% CI 0.1 to 470); machinists (OR 4.3, $95 \%$ CI 0.6 to 29.2 ); railway transport workers not elsewhere classified (OR 4.2, 95\% CI 0.6 to 26.7); hairdressers and barbers (OR $4.1,95 \%$ CI 0 to 502 ); and welders (OR 3.1, $95 \%$ CI 0 to 267 ). Only the railway workers and machinists had at least three cases, but no pattern of duties or exposures was found within these occupational groups. All of the occupational groups that had ORs $>3.0$ in the analysis of all histologies had decreased risks for those ever employed in this analysis, indicating that the risks were not specific to squamous cell carcinoma. All the remaining occupational groups originally suspected of being at high risk had ORs $<1.0$ in this analysis. There were no pulp and paper mill workers or painters with this histology.

Adjustment for nasal polyps and decongestant use did not change the results sufficiently to alter the interpretation of the occupational analyses.

\section{BLADDER CANCER}

Table 3 shows the associations between occupation and bladder cancer. Plumbers and pipefitters had an infinite relative risk, based on only one case. Sheetmetal workers had an OR of 5.4. Two of the four sheetmetal worker cases (but not the control) had worked in aircraft assembly, a job which has been reported to have exposure to carcinogenic aromatic amines. ${ }^{23}$

Miners, drillers, and blasters had an OR of 4.5 in the ever employed analysis. The relative risk estimate increased with duration of employment ( $\geqslant 10$ years, OR 8.1). All but one case in this occupational group were men. Twelve cases and four controls mined underground where diesel exhaust fumes and oil mist exposures are often high. The most commonly named types of mines were gold (six cases, three controls), nickel (four cases, one control), and coal (three cases, one control).

Strongly increased ORs were measured in two other occupational groups in the ever employed analyses: hairdressers and barbers; and gardeners. All three cases in the hairdressers and barbers group recalled applying hair dyes. The control, who was a barber, did not. Gardeners had increased risk with increased duration of employment ( $\geqslant 10$ years, OR infinity). There was no pattern of duties or exposures in this occupational group.

Among occupations shown to have increased risks in other studies, several had increased ORs in the ever employed analysis: painters; laundry personnel; chemical and petroleum workers; machinists; and textile workers. Except for the chemical workers, all of these had increased risks with $\geqslant 10$ years of exposure. Only laundry workers and machinists showed consistent patterns of duties or exposures. Three of the laundry worker cases worked in dry cleaning, versus one control. Five machinist cases and three controls worked in traditional machine shops, doing metal grinding, drilling, and lathe work. All reported using cutting oils.

There were also some occupational groups, considered potentially at risk based on evidence from other studies, which did not have increased ORs in the ever employed analysis: smelter and foundry workers; motor vehicle operators; cooks; vehicle mechanics; and shoe and leather workers.

Sex specific analyses did not show any important differences from the sex adjusted analyses.

The cases of bladder cancer had the following histologies: 55 transitional cell carcinomas; 43 papillary transitional cell carcinomas; four squamous cell carcinomas; one adenocarcinoma; one colloid carcinoma; and one carcinoma not otherwise specified. As the papillary, 
Table 3 Odds ratios * showing associations between occupational groups and cancer of the urinary bladder, all cases ( $n=105)$ and controls ( $n=139)$ included

\begin{tabular}{|c|c|c|c|c|c|c|}
\hline & \multicolumn{3}{|l|}{ Ever employed } & \multicolumn{3}{|c|}{ Most recent 20 years removed } \\
\hline & Cases/controls $n$ & Ever employed $O R$ & $95 \% C I$ & Cases/controls $n$ & Ever employed $O R$ & $95 \% C I$ \\
\hline \multicolumn{7}{|l|}{ Occupational groups with $\mathrm{OR} \geqslant 3.0$ : } \\
\hline Plumbers and pipefitterst & $1 / 0$ & $\infty$ & $0.1-\infty$ & $1 / 0$ & $\infty$ & $0.1-\infty$ \\
\hline Sheet metal workerst & $4 / 1$ & 5.4 & $0.5-283$ & $4 / 1$ & 5.4 & $0.5-283$ \\
\hline Miners, drillers, and blasters & $19 / 6$ & 4.5 & $1.6-14.7$ & $18 / 6$ & 3.9 & $1.4-12.5$ \\
\hline Hairdressers, barbers & $3 / 1$ & 3.2 & $0.2-176$ & $2 / 1$ & 2.6 & $0.1-159$ \\
\hline Gardeners & $6 / 3$ & 3.7 & $0.7-25.0$ & $5 / 3$ & 2.7 & $0.5-19.8$ \\
\hline \multicolumn{7}{|l|}{ Occupational groups originally suspect: } \\
\hline Painters & $4 / 3$ & 2.8 & $0.4-21.3$ & $2 / 2$ & 2.0 & $0.1-33.0$ \\
\hline Laundry personnel & $5 / 4$ & 2.3 & $0.4-13.9$ & $4 / 4$ & 1.8 & $0.3-11.3$ \\
\hline Chemical and petroleum workers & $15 / 10$ & 1.8 & $0.7-4.9$ & $14 / 7$ & 2.2 & $0.8-6.8$ \\
\hline Machinists $†$ & $8 / 7$ & 1.6 & $0.5-5.7$ & $7 / 6$ & 1.6 & $0.4-6.3$ \\
\hline Textile workers & $3 / 3$ & 1.5 & $0.2-13.5$ & $3 / 3$ & 1.5 & $0.2-13.5$ \\
\hline Smelter and foundry workers $\dagger$ & $6 / 8$ & 1.0 & $0.3-3.3$ & $6 / 6$ & 1.3 & $0.3-5.1$ \\
\hline Motor vehicle operators & $21 / 26$ & 0.9 & $0.4-1.9$ & $21 / 22$ & 1.1 & $0.5-2.4$ \\
\hline Cooks & $7 / 12$ & 0.8 & $0.2-2.3$ & $5 / 9$ & 0.7 & $0.2-2.7$ \\
\hline Vehicle mechanics $†$ & $12 / 17$ & 0.7 & $0.3-1.7$ & $11 / 17$ & 0.7 & $0.3-1.6$ \\
\hline Shoe and leather workers & $2 / 6$ & 0.4 & $0-2.6$ & $2 / 5$ & 0.4 & $0-2.9$ \\
\hline \multicolumn{7}{|l|}{ Other occupational groups: } \\
\hline Administrators, managers & $22 / 23$ & 1.3 & $0.6-2.7$ & $14 / 16$ & 1.0 & $0.4-2.4$ \\
\hline Travelling managers and salesmen & $19 / 32$ & 0.7 & $0.3-1.5$ & $14 / 25$ & 0.7 & $0.3-1.4$ \\
\hline Accountants, book-keepers & $13 / 18$ & 1.1 & $0.5-2.7$ & $13 / 17$ & 1.2 & $0.5-2.9$ \\
\hline Engineers, designers $\dagger$ & $4 / 5$ & 1.3 & $0.3-6.6$ & $3 / 3$ & 1.6 & $0.2-12.5$ \\
\hline Teachers, librarians & $10 / 12$ & 1.2 & $0.4-3.5$ & $9 / 7$ & 1.7 & $0.5-5.9$ \\
\hline Sales clerks & $28 / 38$ & 1.0 & $0.5-1.9$ & $24 / 31$ & 1.0 & $0.5-2.0$ \\
\hline Office clerks and secretaries & $19 / 23$ & 1.3 & $0.6-2.9$ & $15 / 21$ & 1.0 & $0.4-2.3$ \\
\hline Healthcare workers & $6 / 9$ & 0.9 & $0.2-3.3$ & $5 / 8$ & 0.8 & $0.2-3.2$ \\
\hline Chemical and biological laboratory personnel & $6 / 8$ & 1.1 & $0.3-3.9$ & $5 / 7$ & 0.9 & $0.2-3.6$ \\
\hline Radio operators $\dagger$ & $7 / 7$ & 1.2 & $0.4-4.3$ & $7 / 7$ & 1.2 & $0.4-4.3$ \\
\hline Surveyors, prospectors, trappers $\dagger$ & $7 / 6$ & 1.4 & $0.4-5.5$ & $5 / 6$ & 1.0 & $0.2-4.3$ \\
\hline Warehouse clerks and labourers & $26 / 31$ & 0.9 & $0.5-1.9$ & $22 / 24$ & 1.0 & $0.5-2.2$ \\
\hline Delivery personnel, unmotorised & $16 / 33$ & 0.6 & $0.3-1.1$ & $15 / 31$ & 0.5 & $0.2-1.1$ \\
\hline Firefighters $\dagger$ & $1 / 4$ & 0.4 & $0-4.6$ & $14 /$ & 0.4 & $0-4.6$ \\
\hline Guards, police & $10 / 8$ & 1.7 & $0.6-5.1$ & $7 / 2$ & 4.6 & $0.8-46.4$ \\
\hline Armed forces personnel, nec & $38 / 32$ & 1.5 & $0.8-3.0$ & $38 / 32$ & 1.5 & $0.8-3.0$ \\
\hline Janitors & $6 / 11$ & 0.8 & $0.2-2.6$ & $3 / 8$ & 0.5 & $0.1-2.5$ \\
\hline Housekeepers $\ddagger$ & $6 / 11$ & 1.0 & $0.1-6.5$ & $4 / 10$ & 0.4 & $0-2.9$ \\
\hline Handymen and apartment caretakers & $7 / 14$ & 0.6 & $0.2-1.6$ & $4 / 3$ & 0.9 & $0.1-5.9$ \\
\hline Food service personnel & $17 / 24$ & 1.0 & $0.4-2.2$ & $14 / 19$ & 1.0 & $0.4-2.4$ \\
\hline Food processors & $13 / 19$ & 0.9 & $0.4-2.2$ & $11 / 19$ & 0.7 & $0.3-1.8$ \\
\hline Farmers and farm labourers & $39 / 37$ & 1.7 & $0.9-3.1$ & $39 / 36$ & 1.7 & $0.9-3.2$ \\
\hline Fishermen $\dagger$ & $4 / 4$ & 0.9 & $0.2-5.3$ & $4 / 3$ & 1.4 & $0.2-10.0$ \\
\hline Forestry and logging workers $\dagger$ & $15 / 12$ & 1.6 & $0.6-4.0$ & $14 / 11$ & 1.7 & $0.4-4.5$ \\
\hline Sawmill workers $\dagger$ & $15 / 18$ & 1.0 & $0.4-2.3$ & $13 / 17$ & 0.9 & $0.4-2.2$ \\
\hline Pulp and paper mill workers $†$ & $2 / 2$ & 1.5 & $0.1-22.6$ & $2 / 2$ & 1.5 & $0.1-22.6$ \\
\hline Welderst & $4 / 4$ & 0.9 & $0.2-5.6$ & $3 / 3$ & 0.9 & $0.1-7.2$ \\
\hline Construction forement & $8 / 5$ & 1.5 & $0.4-6.0$ & $6 / 4$ & 1.5 & $0.3-8.1$ \\
\hline Construction labourers & $15 / 21$ & 0.8 & $0.3-1.7$ & $14 / 17$ & 0.9 & $0.3-2.1$ \\
\hline Bricklayers, plasterers, and cement workers $\dagger$ & $7 / 7$ & 1.4 & $0.4-5.0$ & $7 / 5$ & 1.9 & $0.5-8.1$ \\
\hline Electricians and electrical equipment installers $\dagger$ & $2 / 9$ & 0.3 & $0-1.6$ & $2 / 7$ & 0.4 & $0-2.0$ \\
\hline Carpenters and wood workers, nect & $18 / 24$ & 0.9 & $0.4-1.9$ & $11 / 22$ & 0.6 & $0.2-1.4$ \\
\hline Heavy equipment operators $\dagger$ & $9 / 7$ & 1.3 & $0.4-4.5$ & $7 / 7$ & 1.0 & $0.3-3.6$ \\
\hline Pilots, aircraft crew† & $4 / 7$ & 0.8 & $0.2-3.2$ & $4 / 7$ & 0.8 & $0.2-3.2$ \\
\hline Railway transport workers, nect & $3 / 8$ & 0.5 & $0.1-2.1$ & $3 / 7$ & 0.6 & $0.1-2.6$ \\
\hline Ship transport workers, nect & $9 / 11$ & 0.9 & $0.3-2.7$ & $9 / 11$ & 0.9 & $0.3-2.7$ \\
\hline Shipbuilding workers, nect & $6 / 5$ & 1.5 & $0.4-6.6$ & $5 / 4$ & 1.8 & $0.4-6.3$ \\
\hline Transport engineers and firement & $3 / 6$ & 0.6 & $0.1-2.7$ & $3 / 6$ & 0.6 & $0.1-2.7$ \\
\hline Stationary engineers, boilermakers $\dagger$ & $6 / 11$ & 0.7 & $0.2-2.1$ & $6 / 11$ & 0.7 & $0.2-2.1$ \\
\hline Service station attendants and managers & $6 / 18$ & 0.3 & $0.1-0.99$ & $5 / 14$ & 0.4 & $0.1-1.1$ \\
\hline Small equipment repairers $t$ & $7 / 10$ & 1.0 & $0.3-3.2$ & $5 / 9$ & 0.8 & $0.2-3.0$ \\
\hline Industrial mechanics $\dagger$ & $10 / 9$ & 1.4 & $0.5-4.2$ & $10 / 8$ & 1.5 & $0.5-4.8$ \\
\hline
\end{tabular}

* Adjusted for sex, age (in 3 strata: $<60,60-69$, and $\geqslant 70$ years), and cigarette smoking (in three strata: 0-9, 10-39, and $\geqslant 40$ pack-years).

$\dagger$ All exposed cases and controls were men.

$\ddagger$ All exposed cases and controls were women. nec $=$ Not elsewhere classified.

transitional, and squamous cell carcinomas all arise from the transitional cell line, and made up $97 \%$ of the tumours, no separate analysis by histology was performed.

Additional adjustment for consumption of coffee, tea, and diet soft drinks, and a history of bladder infections, abdominal injuries, and chemotherapy did not change results sufficiently to alter the interpretation of the occupational analyses.

\section{Discussion}

NASAL CANCER

Increased risks have been measured in textile workers elsewhere. ${ }^{24}$ The specific exposure of interest is not known, although fabric dust has been considered a possibility. ${ }^{25}$ Certain fibres are made from plant materials (cotton, linen, rayon), and may produce exposures similar to furniture workers and cabinet makers. Another similarity is the potential for concurrent exposure to formaldehyde. This chemical is used in permanent press applications and is considered probably carcinogenic by IARC. ${ }^{13}$ Sewing machine oils may also be a carcinogenic exposure. ${ }^{12}$

Among four cases who had worked in the pulp and paper industry, three were known to have been maintenance workers and were likely to have welded or brazed stainless steel. Exposures to nickel and hexavalent chromium are likely in these operations; these metals have 
been consistently associated with increased risks of nasal cancer and are considered to be known carcinogens. ${ }^{16}$ Cohort studies of pulp and paper mill workers in the United States and Finland have not found nasal cancers, although these cohorts and the expected number of cases of nasal cancer (based on population rates) were quite small. ${ }^{29-31}$

Although exposures to chromium, nickel, and formaldehyde were queried in the exposure section of the questionnaire, they were not recalled by the pulp and paper maintenance worker or the textile worker cases. This is likely to be because these agents are constituents of composite materials and therefore not known to employees who are exposed. ${ }^{32}$

Several other occupational groups identified in this study have had increased risks of nasal cancer reported in the scientific literature: miners, drillers, and blasters; ${ }^{24} 2728$ plumbers; ${ }^{26}{ }^{28}$ painters; ${ }^{2433}$ and machinists. ${ }^{26} 28$

We found no associations with occupations exposed to wood dust or wood, in contrast to reported results. ${ }^{13}$ The woods used in this region are almost exclusively softwoods, which have been associated with increased risks of squamous cell carcinomas of the nose and nasal cavities in previous investigations. ${ }^{13435}$ Earlier studies conducted in British Columbia and nearby Washington State accrued cases from 1939 to 1977 and 1979 to 1987 respectively. ${ }^{34}{ }^{35}$ The different result found in this study may reflect evidence that more recent exposures are relatively low (means $<1$ $\mathrm{mg} / \mathrm{m}^{3}$ ) in the major wood industries of this region (construction carpentry and production of primary products from forests)..$^{36}$

No associations were found with other occupational groups originally suspected of being at high risk. Increased risks of nasal cancer have been found elsewhere among nickel refining workers ${ }^{16}$; however, the smelters and foundries in British Columbia are not involved in nickel refining or alloy production. Chemical and biological laboratory personnel may have exposures to formaldehyde. ${ }^{13}$ Although the OR estimate for the occupational group was not increased, both laboratory workers with nasal cancer reported this exposure, whereas half the controls did not. Boot and shoe manufacture and repair have been classified by IARC $^{12}$ as carcinogenic to humans. The lack of association in this study may reflect the fact that shoe and leather work are not usual occupations in British Columbia; only one of the controls had this occupation in this province.

\section{BLADDER CANCER}

Increased risks of bladder cancer among miners have been reported elsewhere. ${ }^{83-43}$ Diesel equipment is commonly used in above ground and underground operations, as is drilling equipment with cutting oils (Tom Carter, British Columbia Ministry of Energy, Mines, and Petroleum Resources, personal communication, 8 August 1994). Diesel exhaust has been designated as probably carcinogenic by IARC, and mineral oils have been designated as known human carcinogens. ${ }^{12-14}$
Hairdressers and barbers have shown increased risks of bladder cancer in numerous studies. ${ }^{83839} 42-47$ The IARC recently classified the occupations, hairdresser and barber, as probably carcinogenic to humans. ${ }^{15}$ The suspected carcinogenic exposures include hair dyes, as well as coal tar derivatives and oils. ${ }^{15}$

Laundry personnel have been shown to have increased risks in many epidemiological studies. ${ }^{39} 4448$ The chlorinated aliphatic hydrocarbons, including carbon tetrachloride and perchloroethylene, have been postulated as aetiological agents; carbon tetrachloride was classified as possibly carcinogenic and perchloroethylene as probably carcinogenic by IARC. ${ }^{12} 49$

Increased risks of bladder cancer among machinists have been reported elsewhere. $.^{38} 40-424450$ The carcinogenic exposures of machinists cutting and grinding metals may include polycyclic aromatic hydrocarbons in used mineral oils and aromatic amines in synthetic cutting oils. ${ }^{12}$

Occupational groups with increased relative risks, but without clear patterns of job duties or exposures in this study have also been reported previously in the epidemiological literature as being associated with bladder cancer: painters; ${ }^{103640-4451}$ tailors and textile workers; $83639-41434451-53$ and chemical and pe-

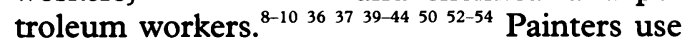
various pigments, extenders, and solvents; this job has been classified as carcinogenic to humans by IARC, ${ }^{55}$ largely based on stronger evidence for lung cancer than bladder cancer. Tailors and textile workers may also have exposure to pigments and dyes. Several occupations with exposures to inks, aromatic amines, polycyclic aromatic hydrocarbons, and coal tars were included in the occupational group chemical and petroleum workers: printers, hot tar roofers, rubber processors, coal workers, and oilfield manual workers.

Three other occupations with increased risk estimates in this study have had fewer reports of positive associations with bladder cancer. Increased risks have been detected among plumbers, ${ }^{36} 3852$ sheet metal workers, ${ }^{36}$ and gardeners or nurserymen. ${ }^{4-42}$

Several occupations which were originally suspected of being at high risk had no association with bladder cancer in this study. Consistently increased risks of bladder cancer have been found for aluminum production; the process has been classified by IARC as carcinogenic to humans. ${ }^{12}$ The group smelter and foundry workers included one case and three controls who had worked at an aluminum smelter. The lack of an association in this study may be related to the case definition (see limitations).

Motor vehicle operators have often had increased risks of bladder cancer reported, although relative risks have generally been low. ${ }^{37} 384042445051535456$ Our results are consistent with several other studies which have found no excess risk. ${ }^{864153}$ A possible explanation for the lack of association in this study may be the rural and wilderness settings for much western Canadian vehicle traffic, unlike the urban 
settings which may predominate elsewhere. Most studies which have examined vehicle mechanics as an occupational category have found increased risks. ${ }^{38} 40-435456$ Our study had results similar to others which did not. ${ }^{445}$

Although cooks and kitchen workers have shown increased risks in some studies, ${ }^{9243}$ our results are consistent with those from several other recent studies which found no association. ${ }^{41445}$ Leather workers have shown increased risks of bladder cancer in many studies, ${ }^{9} 364042435156$ although several reports have shown no excess. ${ }^{83744}$ As for nasal cancer, the lack of association for shoe and leather workers may simply reflect the paucity of leather working occupations within British Columbia.

LIMITATIONS

The main limitation of this study was its small size, resulting in imprecise $O R$ estimates. Looking for patterns of duties or exposures among at least three cases in an occupational group, as well as increased relative risks, acted as a check for selecting occupations of interest for surveillance follow up.

Grouping of jobs meant that people with different work duties and exposures were included in the same occupational group, usually expected to result in non-differential misclassification and bias of risk estimates to the null. ${ }^{57}$ This may have been a special issue for trades occupations the exposures of which would also be influenced by their industry of employment. As a check, we looked for patterns of exposure among occupations with increased ORs, and if they suggested an industry of interest, all the job listings for that industrial code were examined descriptively.

This study excluded carcinomas in situ. The natural history of many bladder cancers may include a prolonged period (years) of transitional cell carcinoma in situ before development of invasive carcinoma. Difficulty in classifying a tumour as invasive or in situ was responsible for most of the changes in histological eligibility of bladder cancer in this study. Some epidemiologists have recommended that in situ carcinomas be included in case definitions ${ }^{1051}$; however, comparisons of occupational associations with invasive and in situ cancers in the United States national bladder cancer study indicated that risks were very similar. ${ }^{58}$ Therefore exclusion of in situ tumours should not bias results, except when at risk occupational groups are screened to allow early detection. This may have been the case for aluminum smelter workers in British Columbia, who were made aware of their risk in a recent cohort study. ${ }^{59}$

\section{SURVEILLANCE FOLLOW UP}

Results from these studies were used to select occupations which warranted follow up investigations in British Columbia work sites. Two occupational groups with increased risks of nasal cancer and three or more cases with similar duties or exposures were selected: textile workers (suspect exposures: formaldehyde, oils, fabric dust); and pulp and paper workers (suspect exposures: chromium and nickel from stainless steel welding or brazing in maintenance jobs). These jobs were held by 10 cases, representing $21 \%$ of the cases of nasal cancer. None had been recognised previously in compensation claims or penalty actions by the local regulatory agency despite evidence linking the job or its exposures to nasal cancer in the scientific literature.

Four occupations had increased risks of bladder cancer and showed shared patterns of job duties or exposures among three or more cases: mining (suspect exposures: diesel exhaust and oil mist); machining (suspect exposures: polycylic aromatic hydrocarbons and aromatic amines in cutting oils); hairdressing (suspect exposures: hair dyes as well as coal tar derivatives and oils); and drycleaning (suspect exposures: volatile chlorinated aliphatic hydrocarbons). These jobs were held by 33 cases, representing $31 \%$ of the cases of bladder cancer. Two of these occupations had not been previously recognised by the local regulatory agencies, in either penalty actions or compensation claims: hairdressers, and machinists.

The value of disease surveillance in this study will only be known after workplace follow up determines whether exposures to carcinogens continue in the targeted occupations. The responsible British Columbia regulatory agencies, as well as occupational hygienists in the pulp and paper industry have been informed of the study results to target exposure measurements and control strategies. Some of the targeted occupations are found in small shops which are unlikely to employ professional health and safety personnel. Without attention from regulatory agencies, exposures to carcinogens in these work sites are unlikely to be recognised.

We thank the following people for their assistance during the design, conduct, or analysis of this study: Jody Slakov, Dr Pau Demers, Ruth Hershler, Dr Clyde Hertzman, Bob Hirtle, D Steve Marion, Dr Anne Milner, and Hazel Sarginson. We are grateful to all the cases, controls, and next of kin who gave their time to take part in this study. The study was supported by the British Columbia Health Research Foundation.

1 Registrar General. Occupational mortality, decennial supple ment for Great Britain, 1982-3. London: Her Majesty's Stationery Office, 1986.

2 Rutstein DD, Mullan RJ, Frazier TM, Halperin WE, Meliu JM, Sestito JP. Sentinel health events (occupational): basis for physician recognition and public health surveillance. Am F Public Health 1983;73:1054-61.

3 Matte TD, Baker EL, Honchar PA. The selection and definition of targetted work-related conditions for surveillance under SENSOR. Am ₹ Public Health 1989;79(suppl):21-5.

4 Weinstein AL, Howe HL, Burnett WS. Sentinel health event Weinstein AL, Howe HI, Burnett WS. Sentinel health event
surveillance: skin cancer of the scrotum in New York State. surveillance: skin cancer of the scrotum

5 Paci E, Dini S, Buiatti E, Costantini AS, Lenzi S, Zappa M Malignant mesothelioma in non-asbestos textile workers in Florence. Am ₹ Ind Med 1987;11:249-54.

6 Veys CA. Bladder tumors and occupation: a coroner's notification scheme. $\mathrm{Br} \mathcal{F}$ Ind Med 1974;31:65-71.

7 Teschke K, Morgan MS, Checkoway H, Franklin G, Spinell $J$, van Belle G, Weiss NS. Mesothelioma surveillance to locate sources of exposure to asbestos. Can $\mathcal{F}$ Public Health 1997; (in press).

8 Anthony HM, Thomas GM. Tumors of the urinary bladder: an analysis of the occupations of 1030 patients in Leeds, England. $f$ Natl Cancer Inst 1970;45:879-95.

9 Cole P, Hoover R, Friedell GH. Occupation and cancer of the lower urinary tract. Cancer 1972;29:1250-60.

10 Morrison AS, Ahlbom A, Verhoek WG, Aoki K, Leck I, Ohno Y, Obata K. Occupation and bladder cancer in BosOhno Y, Obata K. Occupation and bladder cancer in Boston, USA, Manchester, UK, and Nagoya,

11 McDonald AD, McDonald JC. Malignant mesothelioma in North America. Cancer 1980;46:1650-6. 
12 International Agency for Research on Cancer. Monographs on the evaluation of the carcinogenic risk of chemicals to humans. Overall evaluations of carcinogenicity: an updating of IARC monographs. Vols 1 to 42 (suppl 7). Lyon: IARC Sci Publ, 1987.

13 International Agency for Research on Cancer. Monographs on the evaluation of carcinogenic risks to humans. Wood dust and formaldehyde. Vol 62. Lyon: IARC Sci Publ, 1995.

14 International Agency for Research on Cancer. Monographs on the evaluation of carcinogenic risks to humans. Diesel and gasoline engine exhausts and some nitroarenes. Vol 46. Lyon: IARC Sci Publ, 1989.

15 International Agency for Research on Cancer. Monographs on the evaluation of carcinogenic risks to humans. Occupational exposures of hairdressers and barbers and personal use of hair colorants; some hair dyes, cosmetic colorants, industrial dyestuffs and aromatic amines. Vol 57. Lyon: IARC Sci Publ, 1993.

16 International Agency for Research on Cancer. Monographs on the evaluation of carcinogenic risks to humans. Chromium, nickel and welding. Volume 49. Lyon: IARC Sci Publ, 1990.
nium,

17 International Agency for Research on Cancer. Cross index of synonyms and trade names in volumes 1 to 26. Monographs on the evaluation of the carcinogenic risk of chemicals to humans (suppl 3). Lyon: IARC Sci Publ, 1982.

18 Gosselin RE, Smith RP, Hodge HC. Clinical toxicology of commercial products. 5th ed. Baltimore: Williams and Wilkins, 1984

19 Statistics Canada. Standard industrial classification. Ottawa: Minister of Supply and Services, 1980.

20 Statistics Canada. Standard occupational classification. Ottawa: Minister of Supply and Services, 1980.

21 Breslow NE, Day NE. Statistical methods in cancer research. Lyon: IARC Sci Publ, 1980:140.

22 Mehta CR, Patel NR, Gray R. Computing an exact confidence interval for the common odds ratio in several $2 \times 2$ contingency tables. Fournal of the American Statistical Association 1985;80:969-73.

23 Sieber WK, Sundin DS, Young RO. Development of a job exposure matrix. The changing nature of work and workforce, third foint US - Finnish Science Symposium, Frankfort, Kentucky: October 22-24, 1986.

24 Acheson ED, Cowdell RH, Rang E. Adenocarcinoma of the nasal cavity and sinuses in England and Wales. $\mathrm{Br} F$ Ind Med 1972;29:21-30.

25 Brinton L, Blot W, Fraumeni J. Nasal cancer in the textile and clothing industries. $\mathrm{Br} \mathcal{F}$ Ind Med 1985;42:469-74.

26 Malker H, McLaughlin J, Blott W, Weiner J, Malker B, Ericson J, Stone B. Nasal cancer and occupation in Sweden, 1961-79. Am f Ind Med 1986;9:477-85.

27 Comba P, Battista G, Belli S, de Capua B, Merler E, Orsi D $e t$ al. A case-control study of cancer of the nose and paranasal sinuses and occupational exposures. Am $\mathcal{F}$ Ind Med 1992:22:511-20.

28 Luce D, Leclerc A, Morcet J-F, Casal-Lareo A, Gérin M, Brugère $\mathrm{J}$, et al. Occupational risk factors for sinonasal cancer: a case-control study in France. Am $\mathcal{F}$ Ind Med 1992;21:163-75.

29 Henneberger PK, Ferris BG, Monson RR. Mortality among pulp and paper workers in Berlin, New Hampshire. Brf Ind Med 1989;46:658-64.

30 Jappinen P; Hakulinen T, Pukkala E, Tola S, Kurppa K. Cancer incidence of workers in the Finnish pulp and pape industry. Scand $\mathcal{F}$ Work Environ Health 1987;13:197-202.

31 Robinson CF, Waxweiler RJ, Fowler DP. Mortality among production workers in pulp and paper mills. Scand $\mathcal{F}$ Work production workers in pulp and
Environ Health 1986;12:552-60.

32 Teschke K, Kennedy SM, Olshan AF. Effect of different questionnaire formats on reporting of occupational exposures. $A m$ F Ind Med 1994;3:327-37.

33 Luce D, Gérin M, Leclerc A, Morcet J-F, Brugere J, Goldberg $M$. Sinonasal cancer and occupational exposure to formaldehyde and other substances. Int $\mathcal{F}$ Cancer 1993;53: 224-31.

34 Vaughan T, Scott D. Wood dust exposure and squamous cell cancers of the upper respiratory tract. $A m \mathcal{F}$ Epidemio 1991;133:560-4

35 Elwood JM. Wood exposure and smoking: association with cancer of the nasal cavity and paranasal sinuses in British Columbia. Can Med Assoc F 1981;124:1573-7.
36 Teschke K, Hertzman C, Morrison B. Level and distribution of employee exposures to total and respirable wood dust in two Canadian sawmills. Am Ind Hyg Assoc $\mathcal{F} 1994$; 55:245-50.

37 Vedal S, Chan-Yeung M, Enarson D, Fera T, Maclean L, Tse KS, Langille R. Symptoms and pulmonary function in western red cedar workers related to duration of employwestern red cedar workers related to duration of employment and $179-83$.

38 Wynder E, Onderdonk J, Mantel N. An epidemiological investigation of cancer of the bladder. Cancer 1963;16: 1388-407.

39 Silverman D, Hoover R, Albert S, Graff KM. Occupation and cancer of the lower urinary tract in Detroit. $\mathcal{F}$ Natl Cancer Inst 1983;70:237-45.

40 Brownson R, Chang J, Davis J. Occupation, smoking, and alcohol in the epidemiology of bladder cancer. Am $\mathcal{F}$ Public Health 1987;77:1298-300.

41 Dolin P. A descriptive study of occupation and bladder cancer in England and Wales. Br $\mathcal{F}$ Cancer 1992;65:476-8.

42 Howe GR, Burch JD, Miller AB, Cook GM, Morrison B, Gordon $\mathrm{P}$, et al. Tobacco use, occupation, coffee, various nutrients, and bladder cancer. $\mathcal{F}$ Natl Cancer Inst 1980;64: 701-13.

43 Cordier S, Clavel J, Limasset J-C, Boccon-Gibod, Le Moual $\mathrm{N}$, Mandereau L, Hémon D. Occupational risks of bladder cancer in France: a multicentre case-control study. Int $\mathcal{F}$ Epidemiol 1993;22:403-11.

44 Silverman DT, Levin LI, Hoover RN, Hartge P. Occupational risks of bladder cancer in the United States: I White men. $\mathcal{F}$ Natl Cancer Inst 1989;81:1472-9.

45 Schoenberg JB, Stemhagen A, Mogielnicki AP, Altman R, Abe T, Mason TJ. Case-control study of bladder cancer in New Jersey. 1 Occupational exposures in white males. $f$ Natl Cancer Inst 1984;72:973-81.

46 Claude J, Frentzel-Beyme R, Kunze E. Occupation and risk of cancer of the lower urinary tract among men. A of cancer of the lower urinary tract amon
case-control study. Int $\mathcal{F}$ Cancer 1988;41:371-9.

47 Silverman $D$, Levin $L$, Hoover $R$. Occupational risks of bladder cancer among white women in the United States. Am F Epidemiol 1990;132;453-61.

48 Weiss NS. Cancer in relation to occupational exposure to perchloroethylene. Cancer Causes Control 1995;6:257-66.

49 International Agency for Research on Cancer. Monographs on the evaluation of carcinogenic risks to humans. Drycleaning, some chlorinated solvents, and other industrial chemicals. Vol 63. Lyon: IARC Scientific Publications, 1995.

50 Schifflers E, Jamart J, Renard V. Tobacco and occupation as risk factors in bladder cancer: a case-control study in risk factors in blader Belgium. Int $f$ Cancer 1987;39:287-92.

51 Jensen OM, Wahrendorf J, Knudsen JB, Sorensen BL. The Copenhagen case-referent study on bladder cancer. Scand Copenhagen case-referent study on bladde

52 Burns P, Swanson G. Risk of urinary bladder cancer among blacks and whites: the role of cigarette use and occupation. Cancer Causes Control 1991;2:371-9.

53 Risch H, Burch J, Miller A, Hill G, Steele, Howe G. Occupational factors and the incidence of cancer of the bladder in Canada. Br F Ind Med 1988;45:361-7.

54 Bonassi S, Merlo F, Pearce N, Puntoni R. Bladder cancer and occupational exposure to polycyclic aromatic hydrocarbons. Int $\mathcal{f}$ Cancer $1989 ; 44: 648-51$.

55 International Agency for Research on Cancer. Monographs on the evaluation of carcinogenic risks to humans. Some organic solvents, resin monomers and related compounds, pigments and solvents, resin monomers and related compounds, pigments and
occupational exposures in paint manufacture and painting. Vol occupational exposures in paint man

56 Vineis $P$, Magnani C. Occupation and bladder cancer in males: a case-control study. Int $\mathcal{f}$ Cancer 1985;35:599-606.

57 Copeland KT, Checkoway H, McMichael AJ, Holbrook $\mathrm{RH}$. Bias due to misclassification in the estimation of relative risk. Am $\mathcal{F}$ Epidemiol 1977;105:488-95.

58 Sturgeon SR, Hartge P, Silverman DT, Kantor AF, Linehan WM, Lynch C, Hoover RN. Associations between bladder cancer risk factors and tumor stage and grade at diagnosis. Epidemiology 1994;5:218-25.

59 Spinelli JJ, Band P, Svirchev L, Gallagher R. Mortality and cancer incidence in aluminum reduction plant workers. $f$ Occup Med 1991;33:1150-5. 